\title{
Improving The Intangible Assets Accounting: In A Pandemic Period
}

\author{
${ }^{1}$ Rizaev Nurbek Kadirovich, ${ }^{1}$ Temirkhxanova Mutabar Juraevna, ${ }^{2}$ Li Shaomin \\ ${ }^{1}$ DSc, Tashkent Financial Institute, Uzbekistan. \\ ${ }^{2}$ Researcher at the Tashkent state economic university, Uzbekistan. \\ E-mail: mutabarchik@mail.ru
}

\begin{abstract}
This article provides information on the impact of the pandemic on intellectual property and its consequences, the activities of companies providing intellectual property services in the context of the pandemic, the intellectual ecosystem. Also, this article is devoted to the consideration of issues related to the creation of the intellectual property ecosystem throughout the world, research and experimental developments, R\&D expenses, as well as accounting and assessment of inovation products.
\end{abstract}

Keywords:

intellectual property, pandemic, ecosystem, artificial property, additive technology, research and development, patent, industrial sample, useful model, invention, accounting, civil code, items from internet, intellectual property agency.

Article Received: 18 October 2020, Revised: 3 November 2020, Accepted: 24 December 2020

\section{Introduction}

It is known that the power of the coronavirus pandemic (COVID-19) has almost stopped the world economy. This unexpected biological catastrophe has affected the activities of all major companies and firms that are shaking the world economy. As a result of the pandemic, companies are facing a number of challenges in making their operational and strategic management decisions. The potential economic damage from the disaster is estimated at trillions of dollars. Global growth is slowing. Despite efforts by the world community, including the World Health Organization (WHO), to reduce the spread of the pandemic, many of the world's largest companies and firms are still struggling to contain their economic and financial activities. or are forced to drive, at least in part. In countries where COVID-19 is prevalent, not only large companies but also small and medium-sized businesses are suffering. Significantly, this pandemic has had a significant negative impact on the development of human intellectual property.

It should be noted that the measures taken around the world to prevent the pandemic have opened a new page in the process of legalization of intellectual property, which means that many patent offices have switched to remote operation. In the registration of intellectual property, ie applications and applications to patent offices are carried out online. In today's pandemic, agencies and organizations that provide services in the field of intellectual property are working at a distance. In particular, in accordance with the Resolution of the Cabinet of Ministers of the Republic of Uzbekistan dated March 23, 2020 "On additional measures against the spread of coronavirus infection", the staff of the Intellectual Property Agency under the Ministry of Justice organized remote work. In this case, citizens who apply to the Agency can contact the selected department.So, whether we like it or not, we have to get used to working and living in a pandemic.

Currently, human capital, intellectual potential, innovative ideas, as well as high technologies in innovative globalization constitute the basis for rapid and sustainable development. As far as we know, currently the volume of the market of intellectual property objects and innovation products is rapidly increasing throughout the world. In particular, the market of "artificial intelligence"- (AI) rose from 31 percent and in 2017 this indicator accounted for 3 billion USD, and in 2018 this figure constituted 8,1 USD 
and this year it has amounted to 13,4 billion UZS. Moreover, it is expected, that by 2022 this indicator will total 52,5 billion UZS (Frost \& Sullivan, 2019). In this regard, such advanced technologies as "SD model" and "Items from Internet" (IoT) are rapidly developing and their market is annually growing by $10-15$ per cent (nowadays this figure accounts for 6 billion USD). This, in turn, requires creation of the intellectual property ecosystem and its further development.

Moreover, development of the intellectual property market will be mainly connected with the creation of this ecosystem. It should be noted, that the concept of "Intellectual property ecosystem" appeared in foreign countries many years ago and currently it has approached the level of development. For example, in the USA the intellectual property ecosystem is referred to the Silicon Valley which unites major venture companies, investors, tart-ups and entrepreneurs. The reason for this that head offices and lab rooms of the famous world-wide known companies and giants of the electronic industry (Apple, Google, Facebook, Intel, AMD, Electronic Arts) are located there. They are involved in the development of intellectual projects and this fact results in the creation and further development of intellectual property ecosystem, which, in turn, leads to ensuring innovative globalization.

The intellectual property ecosystem requires special emphasis on the creation and use of intellectual property through the application of new knowledge and technologies. The growth rates of the global intellectual property market are higher than $10 \%$ per year, and with the figure amount to 23 per cent in China, 5 per cent in the USA and Russia and 2 per cent in France. Over the last decade, more than one billion patented objects have been introduced into digital platforms and services for intellectual property management.

According to the statistical data, "in the economically developed countries the amount of the total assets of the companies constitutes 89,0 trillion USD, out of which assets in tangible form account for 46,8 trillion USD (52,5 per cent), intellectual property objects (goodwill included) amount to 41,9 trillion USD (in particular, 11,8 trillion USD or 28,1 per cent are intangible assets, and 30,1 trillion USD or 71,9 per cent are intangible assets which haven't been revealed). Even though the intangible assets which are unknown or not detected constitute a major part of the total business value in major companies, they are not accounted in the balance. Denmark (61,0 per cent), Switzerland (42,0 percent) and Belgium (41,0 per cent) are the countries with the highest indicators of the unknown or unrevealed intangible assets.

A number of efficient measures are being undertaken in Uzbekistan to shape the intellectual property ecosystem. In particular, in the Innovation Development Strategy of the Republic of Uzbekistan these measures include improvement of the intellectual property assessment mechanisms and raising the amount of the public expenses on the R\&D. In 2021 this indicator is expected to account for 0,8 per cent in the Gross Domestic Product (GDP) and by 2030 the share of the expenses on the R\&D will amount to $1-1,5$ per cent, the share of expenses on the activity of scientists and researchers will constitute 0,4 per cent, and the share of the expenses on the research made in the business sector will amount to 50-55 per cent.

From this point of view, creation and development of the intellectual property ecosystem is the most urgent and top-priority task for the sustainable innovative development of our republic.

\section{Intellectual property and the ways of its creation}

When perceiving the nature of the intellectual property ecosystem, first of all, it is important know what intellectual property is. Currently the economic concepts of "intellectual property", “intellectual asset", "intellectual capital", "intangible asset" and "insignificant or secret items" have various interpretations in different literary sources. In this regard there is the question which concept should be prioritized. It 
should be noted that scholars and experts demonstrate different approaches to this category and in the statutory acts it is also treated differently. Thus, currently there is no perfect definition of these concepts. The resaon for this is there is no limit for the concept of "intellectual" and it is not subject to any standard. In addition, it is a complicated task to determine their value (price) for the goods (which can be sold in the market).

Therefore, there is no precise set or limit in this regard. The technique which is currently considered to be correct, is being applied. In the economic literary sources the word "intellect" originated from the Latin word "intellektus" which means "to know, to understand, to perceive". In the broad sense of this word this term means "human's mental activity, life, and environmental consciousness, as well as the ability to reflect, change, think, read, learn, know the world, and adopt social experience. In this regard intellect includes with such psychological processes as perception, memorizing, thinking, expressing ideas, speaking and can be connected with such social factors as creative skills, mental abilities, intense activity and life experience.

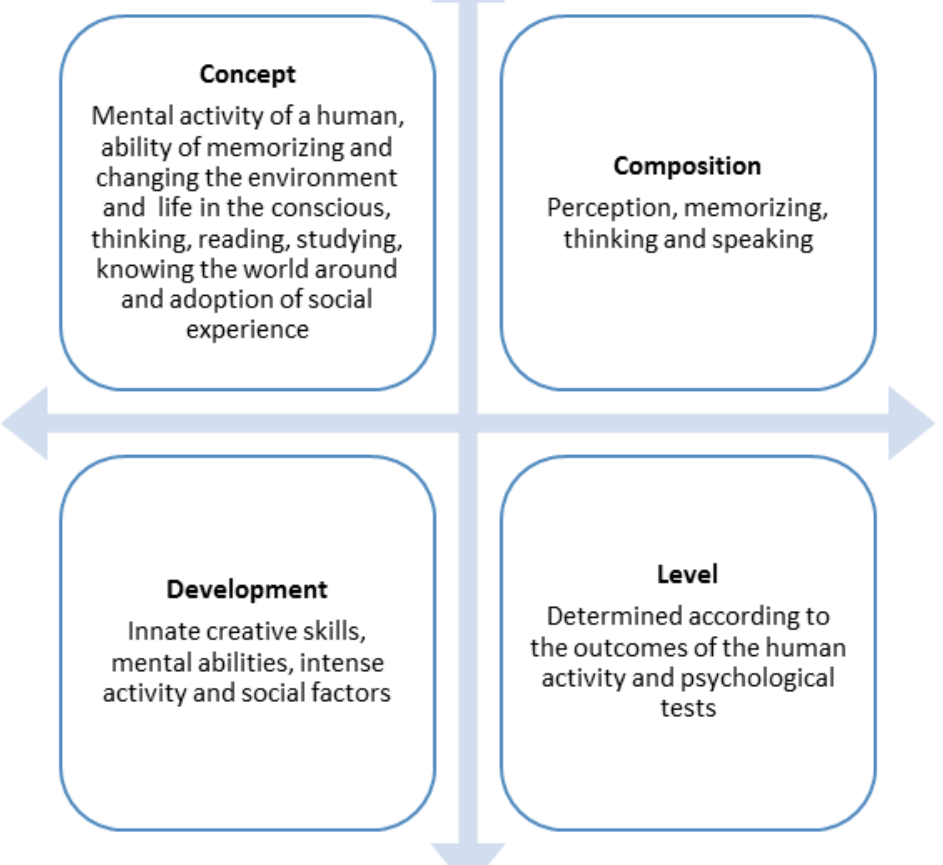

Figure 1. General composition of the "intellect" concept.

\section{International recognition of the intellectual} property

The World Intellectual Property Organization (WIPO) determines the concept of "Intellectual property" as follows: intellectual property refers to creations of the mind: inventions; literary and artistic works; and symbols, names and images used in commerce. Intellectual property is divided into two categories: Industrial Property includes patents for inventions, trademarks, industrial designs and geographical indications".
Various economists define "intellectual property" in the different ways, for example, in the opinion of A. Stewart, intellectual property is the knowledge embodied in a more tangible form than an idea. He approached this concept in terms of production and considers it as the inherent useful knowledge. In this regard intellectual property is a king of useful values in a certain form: a list of facts, database, which, in case of their discovery, can turn into the intellectual property. This means that as a result of useful knowledge there are various insignificant properties but which can create a certain value. 
K. Sveiby considered the concepts of intellectual property and intellectual capital and in his model he divided a company's intangible assets (intellectual property) into there groups: external structure (trade mark, image of the company and production recognition), competence of employees (education, intellectual knowledge, experience and skills), internal structure (patent, copyright, management systems, databases and scientific developments). As it is obvious from this model, intellectual property objects are represented only in the external and internal structures of the company. We do not fully agree with this model as it entirely covered intellectual property objects and approached thereto as intangible assets. If they were intangible assets, the K. Sveiby's model would require a close (alignment) approach to accounting objects.

From the point of view of Thomas P. Carlin, intellectual property represents an ambiguous item in the balance which has a poor quality. In his research he made an emphasis on the value of intellectual property as a key component of intangible assets and justified an opportunity for their assessment. In our opinion, if intellectual property objects had more efficient opportunities for their use, it could be possible to turn into the most profitable asset item of the balance.

B. Leontyev refers intellectual property to the intellectual capital. In addition, he specifies that intellectual property consists of the value of all available assets, intellectual novelties, knowledge, opportunities, and consolidated base of knowledge.

L. Dontsova evaluates intellectual property as a depreciable property of a company from the point of view of economic analysis and considers that their composition includes exclusive rights to various scientific developments, computer programs, patents, copyrights, films, trademarks and service marks. Moreover, she highlights the importance of focusing on receipts (portion of intellectual property) or reducing business costs in determining the economic profit (income) of intellectual property objects and focuses on the analysis methodology for assessing long-term assets of the company.

I. Ivanov considers the concept of intellectual property in terms of the exclusive right of a person to the results of intellectual activity and specifies that it consists of a trademark, a company name, a brand name, and a service mark. He summarizes his views and comes to the conclusion that intellectual property is a part of these intangible assets.

In the opinion of I.Pokrovsky, it is possible to publish and duplicate works without the consent of the owner of intellectual property rights only with the aim of implementing achievements and technical inventions of each owner of the intellectual property (an author).

L. Lytneva evaluates intellectual property as a component of intangible assets and proposes to divide it into the following groups: industrial property objects, objects of copyright and tools for individualization of goods. This classification is practically close to international practice and is grouped according to the intellectual property used by companies.

According to the model of E. Brooklin, intellectual property constitutes an integral part of the company's intellectual capital (Figure 2). According to this model:

Company's intellectual capital > intellectual property > patent, copyright, trade mark, knowhow and service mark.

As it is obvious from the model, intellectual property constitutes a part of intellectual capital by its objects. On the other hand, a trade mark related to the intellectual property object by E.Brooking is recognized as a market asset. 


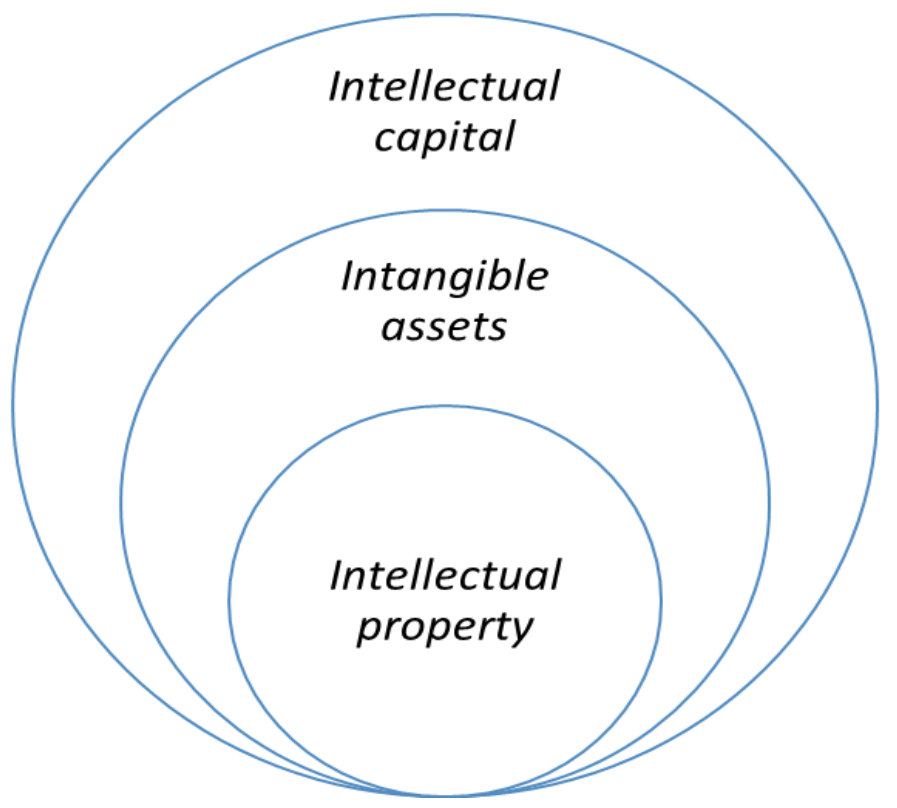

Figure 2. Approaches of E. Brooking, A. Poltorak and P. Lerner to the intellectual property.

Summarizing the above-mentioned statements, in our opinion, the category of intellectual property should be identified as follows: "Intellectual property is knowledge acquired through the human's mental capacity, which requires legal protection as knowledge or an object, or assets (funds)".

In our opinion, intellectual property objects demonstrate the following peculiarities:

first, in most cases, they come in the form of ideas or information;

second, intellectual property in the form of ideas or knowledge cannot be owned unlike owning something in the tangible form;

third, there is also possibility of unlimited use of these objects at any time;

fourth, ownership of intellectual property rights will be canceled after a certain period of time and soon after it will become a common property and can be used freely or without permission;

fifth, exclusive rights, not property rights are applied to intellectual property objects;

sixth, implementation scope of intellectual property is limited to a specific area;

seventh, there are also personal rights of the authors of intellectual property objects, and the users of these objects shall comply with these rights.

Ecosystem as well as its structural composition and elements

The "ecosystem" concept can be applied not only to nature but also to the process of creation and use of intellectual property. This concept originated from the Greek word oikos - housing, residence and system. At that meaning the concept implies organisms living together and a set of conditions in which they live.

The term "ecosystem" was proposed by the plant biologist A. Tansley. In his opinion, in terms of ecology, the ecosystem is a natural unit on Earth that includes all physical organisms, including a set of physical factors, that is, a set of biomass factors (Ekotizim, 2019).

The concept of ecosystems can be applied to objects of varying complexity and size. The intellectual property ecosystem can be comprised not only of innovative products, but also of all technologies and capabilities available in every intellectual property.

This article focuses on the application of this concept to the intellectual abilities of the person and the intellectual property created as a result of this mental activity. In this regard there 
can be the question about the appearance of the intellectual property ecosystem (who are its participants and what are its structural elements)?

In the world practice, the concept of intellectual property ecosystem includes owners of intellectual ideas, creators of intellectual property objects and series of manufacturers of innovation products.

This concept can be expanded by the following statements:

first stage: creators of intellectual ideas or projects (institutes, universities). Projects and developments on the certain intellectual property object, as well as new formulas are created at this stage; second stage: sample and form of intellectual property objects are created at this stage. For example, industrial samples (on spare parts of motor vehicles);

third stage: the sample of the intellectual property object undergoes through experimental testing (industrial samples, useful models and inventions). Then this processed is followed by the commercialization of this product. In particular, herein the industrial production of this sample starts. For example, the industrial sample on the spare part of the motor vehicle is purchased by the manufacturer.

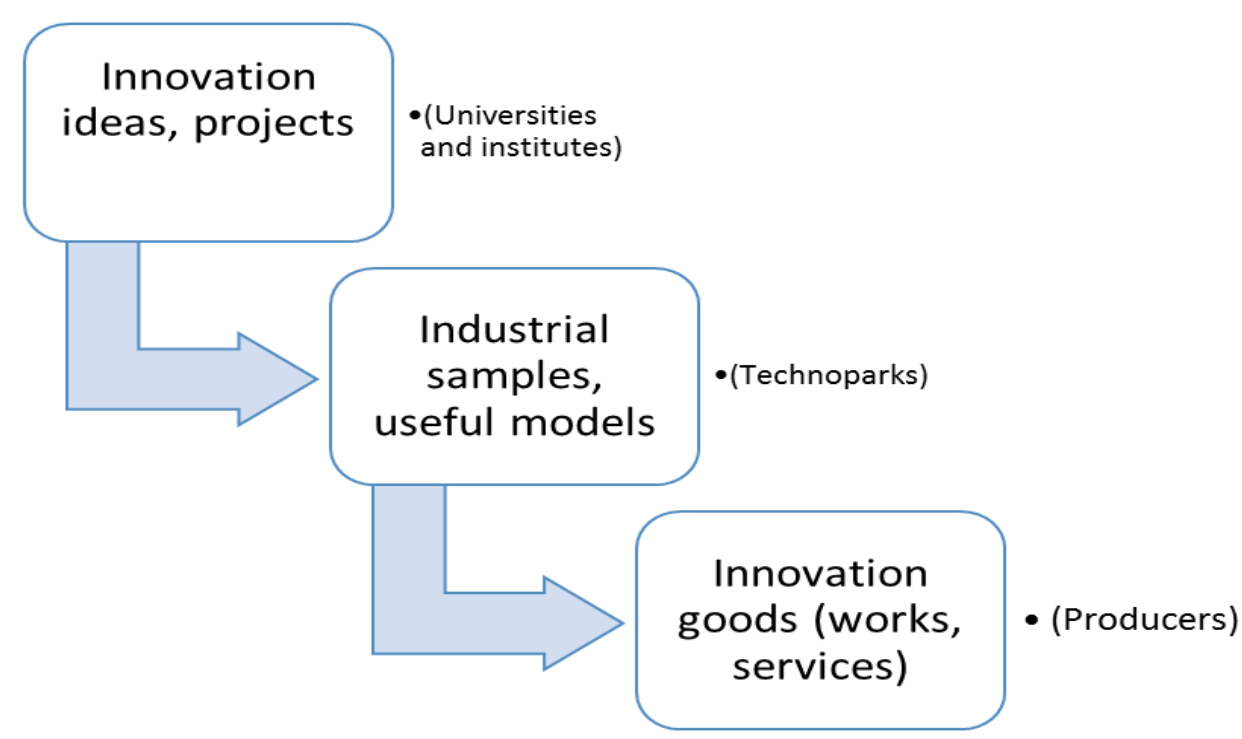

Figure 3. Composition of the intellectual property ecosystem.

Universities and institutes are in the first stage of the intellectual property ecosystem.

Elsewise, intellectual property ecosystem is also called an innovation ecosystem. The innovation ecosystem is a set of human, financial and other resources aimed at enhancing the commercialization of innovation, optimizing and ensuring its efficiency in the process of commercializing ecosystem innovations and their interconnection. 

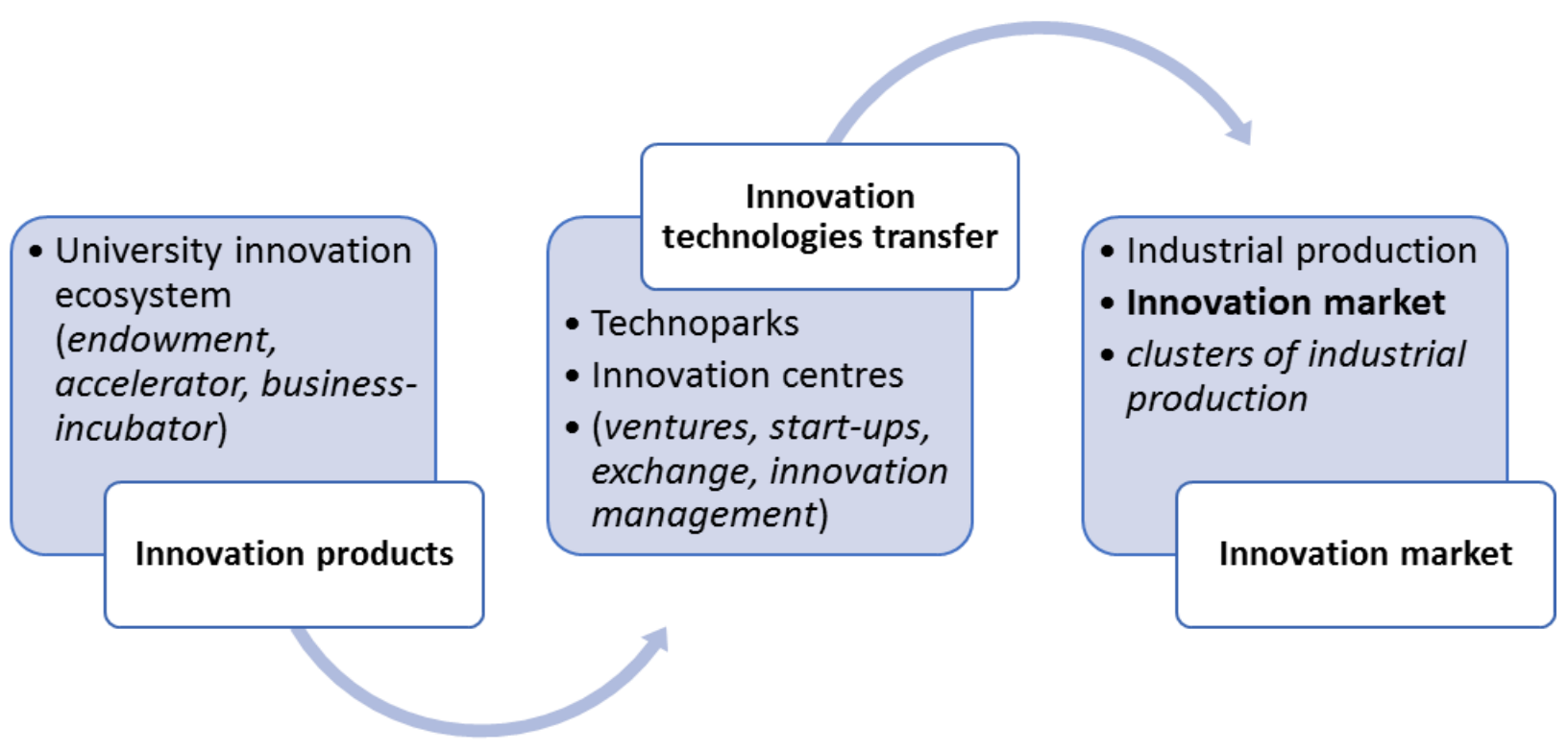

Figure 4. Element of the intellectual property system.

It is obvious from these stages that the intellectual property ecosystem will provide an opportunity for innovative development of the industry in whatever area it is selected. In turn, it results in the increase in the volume of innovative products in the economy. This requires increasing the amount of public expenses on the R\&D and costs on innovations.

\section{Analysis and results}

Analysis of the investment made in the intellectual property

Nowadays there is a tendency to create and develop an "intellectual property ecosystem" throughout the world. In the nearest future decade innovative globalization will lead to the development of the technologies applied to the qualitative changes around the globe. In addition, nowadays the tendency of the formation and development of the "intellectual property ecosystem" hasn't been adequately developed yet.
In this regard it is expected that within next decade huge amounts of investments will be made in such sophisticated technologies as Bio Robot Refrigerators, internet solar panels 5G (Project Skybender), 5D storage devices (Superman memory crystal), oxygen particle injection, underwater transport tunnels (Hyperloop), bioluminescence trees, folding TVs, biological lenses for unusual viewing, spray clothing, DNAoriginated portraits, unmanned vehicles, a city under the dome (Mall of the World), carbon dioxide and solar-fueled artificial leaves, plasma area to protect against accidents, floating cities (Lilypad), 3D printed copies, bionic insects for human organ transplantation operations (BionicANT), search for a new life in a human being that can live 1000 years and another life in space (FAST), etc.

Meanwhile, the amount of expenses made on this sphere is also increasing.

Table 1 : The share of regions in terms of expenditures on research activities in relation to the GDP ( June, 2019, UNESCO)

\begin{tabular}{|l|c|c|}
\hline \multicolumn{1}{|c|}{ Regions of the world } & $\begin{array}{c}\text { Expenditures on R\&D in } \\
\text { relation to the GDP, } \\
\mathbf{\%}\end{array}$ & $\begin{array}{c}\text { Share in relation to } \\
\text { total number of } \\
\text { researchers, \% }\end{array}$ \\
\hline North America and Western Europe & 2,4 & 39,7 \\
\hline East Asia and the Pacific & 2,1 & 38,5 \\
\hline
\end{tabular}




\begin{tabular}{|l|c|c|}
\hline Central-Eastern Europe & 1,0 & 10,6 \\
\hline Latin America and the Caribbean & 0,7 & 3,7 \\
\hline The Arab countries & 0,6 & 3,9 \\
\hline South - West Asia & 0,5 & 1,9 \\
\hline Africa & 0,4 & 1,1 \\
\hline Central Asia & 0,2 & 0,6 \\
\hline
\end{tabular}

In North America and Western Europe, the average amount of expenditures on creating intellectual property constitutes 2,4 percent in relation to the GDP, thus totaling 39,7 percent of researchers around the globe. It is also a high indicator in the countries of East Asia and the Pacific (2,1 percent) and covers 38,5 percent of researchers. However, this situation cannot be considered as positive in the Central Asian region, as the share of expenditure on $R \& D$ amounts to only 0,2 percent in relation to the GDP and the share of developers of innovation products accounts for 0,6 percent.
The analysis illustrates that the main part of expenditures in relation to the GDP refers to the business sector. It is obvious that expenditures directed to business development will be highly efficient. Among the analyzed countries we have the following statistics in terms of creating intellectual property objects (innovation developments): South Korea 78,0 percent (or 57,2 billion UZS), Japan 77,5 percent (131,8 billion UZS), China 77,3 percent (286,5 billion UZS) and the USA 71,4 percent ( 340,7 billion USD).

Table 3: Distribution of overall expenditures on innovation developments

\begin{tabular}{|l|c|c|c|c|}
\hline \multirow{2}{*}{ Countries } & \multicolumn{4}{c|}{ billion USD } \\
\cline { 2 - 5 } & $\begin{array}{c}\text { Business } \\
\text { sector }\end{array}$ & $\begin{array}{c}\text { Public } \\
\text { administration }\end{array}$ & $\begin{array}{c}\text { Education } \\
\text { system }\end{array}$ & $\begin{array}{c}\text { Non- } \\
\text { commercial } \\
\text { sector }\end{array}$ \\
\hline South Korea & 57,2 & 8,2 & 6,6 & 1,1 \\
\hline Japan & 131,8 & 14,1 & 21,3 & 2,2 \\
\hline USA & 340,7 & 54,1 & 62,3 & 19,2 \\
\hline China & 286,4 & 58,6 & 25,5 & - \\
\hline Russia & 24,0 & 12,2 & 3,9 & 0,51 \\
\hline Great Britain & 28,5 & 3,2 & 11,2 & 0,793 \\
\hline India & 17,0 & 29,0 & 1,9 & - \\
\hline Germany & 74,1 & 16,0 & 19,4 & - \\
\hline Sweden & 9,5 & 0,531 & 4,1 & 0,34 \\
\hline France & 38,5 & 7,7 & 13,4 & 0,915 \\
\hline Singapore & 6,2 & 1,1 & 2,7 & - \\
\hline Israel & 9,9 & 0,217 & 1,5 & 0,116 \\
\hline Kazakhstan & 0,263 & 0,235 & 0,159 & 0,60 \\
\hline Uzbekistan & 0,108 & 0,166 & 0,64 & 0,3 \\
\hline
\end{tabular}

According to the data presented in Table 3 it is obvious that in terms of expenditures directed to the education system (universities) which represent the first stage of the intellectual property ecosystem, France is playing a leading role with $34,8 \%$ or 13,8 billion USD, then - Great Britain with $25,5 \%$ (11,2 billion USD) and Germany with $17,7 \%$ (19,4 billion USD). However, in 
terms of creating the innovation production to the public administration, the share of Russia accounts for 12,2 billion USD and the share of India amounts to $60,4 \%$ which equals to 29,0 billion USD.

In Uzbekistan the share of expenditures on the business sector amounts to $31,5 \%$, on the public administration - 48,5 \% and on the education system - 18,7\%, in Kazakhstan these indicators constitute $36,7 \%, 32,7 \%$ and $22,1 \%$ respectively. It should be noted, that from these figures it is obvious that the country focuses on innovation and makes huge investments in innovation developments.

One of the key factors in entering the global innovation index is intellectual property. Therefore, we will focus on the position of
Uzbekistan in the Global Innovation Index. The increase in these indicators has laid the foundation for Uzbekistan to strengthen its position in the Global Innovation Index (GII). As you know the Global Innovation Index (GII) ranks world economies according to their innovation capabilities. Consisting of roughly 80 indicators, grouped into innovation inputs and outputs, the GII aims to capture the multi-dimensional facets of innovation. Despite the pandemic, Uzbekistan entered the Global Innovation Index in 2020. The following table shows the rankings of Uzbekistan, which is a new entry into the GII economy list in 2020.

Table 5: Rankings of Uzbekistan in $\mathbf{2 0 2 0}$

(Source: WIPO, GII: 2020 ranking)

\begin{tabular}{|c|l|c|}
\hline$\#$ & \multicolumn{1}{|c|}{ Indicators } \\
\hline 1. & Global Innovation Index & 93 \\
\hline 2. & Innovation inputs & 81 \\
\hline 3. & Innovation outputs & 118 \\
\hline
\end{tabular}

As can be seen from the table data the statistical confidence interval for the ranking of Uzbekistan in the GII 2020 is between ranks 85 and 109. Uzbekistan performs better in innovation inputs than outputs in 2020. This year Uzbekistan ranks 81st in innovation inputs and 118th in innovation outputs. In 2030, Uzbekistan aims to enter the top 50 in this ranking.

Table 6: Expenditure on R\&D made by the world largest companies

(Source: WIPO Statistics Database, March 2020)

\begin{tabular}{|l|c|c|}
\hline \multicolumn{1}{|c|}{ Firm and companies } & $\begin{array}{c}\text { Expenses, billion Euro } \\
\mathbf{( 2 0 1 9 / 2 0 1 8 )}\end{array}$ & $\begin{array}{c}\text { Growth in \% in 2019 in } \\
\text { relation to 2018 }\end{array}$ \\
\hline Samsung Electronics (Korea) & $14,9 / 13,4$ & 11,1 \\
\hline Apple (USA) & $14,8 / 9,6$ & 15,4 \\
\hline Wolksvagen (Germany) & $14,5 / 13,1$ & 10,6 \\
\hline Microsoft (USA) & $13,6 / 12,2$ & 11,4 \\
\hline Huawei (China) & $12,5 / 11,3$ & 10,6 \\
\hline Intel (USA) & $12,1 / 10,9$ & 11,0 \\
\hline Apple (USA) & $10,7 / 9,6$ & 11,4 \\
\hline Roche (Switzerland) & $9,8 / 8,8$ & 11,3 \\
\hline Johnson \& Johnson (USA) & $9,7 / 8,7$ & 11,4 \\
\hline Daimler (Germany) & $9,6 / 8,6$ & 11,6 \\
\hline
\end{tabular}




\begin{tabular}{|l|c|c|}
\hline Toyota Motor (Japan) & $8,6 / 7,8$ & 10,2 \\
\hline Novartis (Switzerland) & $8,1 / 7,3$ & 10,9 \\
\hline General Motors (USA) & $6,7 / 7,6$ & $-11,9$ \\
\hline
\end{tabular}

The EU Industrial R\&D Investment Scoreboard provides statistic data in the form of rating on the expenses (in the amount of 736,4 billion $€$ ) made by over 2500 companies from 47 countries on the research and development. In particular, 778 US companies (37 \%), 577 companies of the European countries (27\%), 339 Japanese companies $(14 \%), 438$ Chinese companies $(10 \%)$ and 368 companies of other countries $(12 \%)$ invested free funds on the R\&D.

As the data illustrates, the biggest part of investments in terms of budget in the amount of 14,9 billion Euro belongs to Korean company "Samsung Electronics" the US "Apple" company is in the second place in the amount of 14,8 billion Euro and in German company "Volkswagen" this indicator constitutes 14,5 billion Euro. After topthree companies we can see the US company "Microsoft" (13,6 billion Euro), Chinese Huawei company (12,5 billion Euro), and one of the leading USA companies - "Intel" (12,1 billion Euro). Unfortunately, besides two Russian companies - "Kamaz" with 37,0 million Euro ranked 1956 and "Rosneft" with 31,6 million Euro ranked 2193 - none company from the CIS countries has not been included in this rating (Global -2500).

China's Huawei Technology remained the top filer of the PCT international applications in 2019. It was followed by Mitsubishi Electric of
Japan, Samsung Electronics from the Republic of Korea, Qualcomm of the U.S., and Oppo Mobile Telecommunications of China. According to the indicator of the property rights for the intellectual property objects, North East Asia Asian companies are considered to be leading: "Huawei technologies co.,ltd" (4411 in 2019 / 5405 in 2018 / 4024 in 2017, growth by 81,5 \%), "Oppo Mobile" 1927 in 2019, "BOE technology group co.,ltd" (1864/1813/1818, growth by $102,8 \%)$ in China, Mitsubishi electric corporation$2661 / 2812 / 2521$, growth by $94,6 \%$, Sony corporation - 1735 in Japan, LG electronics inc $1646 / 1697 / 1945$, growth by $96,9 \%$, Samsung electronic - 2334/1997/1757, growth by 116,8 \%nt - in Korea.

According to "Madrid agreement" (Madrid top 10 countries) the number of applications submitted for registering trademarks in 2018 accounted for 61200 thousand, and the growth constitutes 108,8 \% (in 2016 this indicator amounted to 56200 thousand). Among the biggest users it is possible to mention the USA, Germany and Cnina and the highest growth of applications submitted for registering trademarks belongs to China $(79,7 \%)$, Russia (36,3 \%) and Japan $(29,1$ $\%)$.

Table 7: Applications submitted for registration of trademarks throughout the world

(Madrid top 10 countries)

\begin{tabular}{|c|c|c|c|c|}
\hline Countries & $\mathbf{2 0 1 6}$ & $\mathbf{2 0 1 7}$ & $\mathbf{2 0 1 8}$ & $\begin{array}{c}\text { Growth in relation to } \\
\mathbf{2 0 1 6} \boldsymbol{\%}\end{array}$ \\
\hline USA & 7730 & 7884 & 8825 & 114,1 \\
\hline Germany & 7545 & 7316 & 7495 & 99,3 \\
\hline China & 3838 & 5230 & 6900 & 179,7 \\
\hline Japan & 2412 & 2495 & 3124 & 129,1 \\
\hline France & 4214 & 4261 & 4490 & 104,7 \\
\hline Great Britain & 3012 & 3292 & 3347 & 111,1 \\
\hline
\end{tabular}




\begin{tabular}{|c|l|l|l|l|}
\hline Switzerland & 3069 & 3272 & 3364 & 109,8 \\
\hline Italy & 3082 & 2878 & 3140 & 101,9 \\
\hline Australia & 2060 & 2115 & 2074 & 100,4 \\
\hline Russia & 1178 & 1460 & 1502 & 136,3 \\
\hline
\end{tabular}

It should be noted that currently the interest of getting a patent for digital technologies in China and South Korea is rapidly increasing. In Germany, the transport sector is considered to be leading in terms of getting patents for digital technologies, but in the USA the leading role belongs to the IT industry. Japan (10,8\%), Germany $(9,9 \%)$ and Korea $(9,3 \%)$ are dominating in the electric machinery and equipment and in the energy sector.

In 2018 throughout the world the volume of patents submitted for trademarks by technologies and research was the highest in the selected countries. Meanwhile, China (16,7 per cent) is dominating by trade marks in terms of trade, i.e. the trademark is the highest in the transport sector. Patent agencies in China, the USA, Japan, South Korea and Europe accepted 84 per cent or 3,1 million applications in terms of issuing patents for created industrial property objects. Herewith, China holds $43,6 \%$ of all patent applications. Moreover, China, the USA, Japan, Europe and India are considered to be leading companies with 58,0 per cent in terms of registering trademarks. In China $(46,3 \%)$ the level of crteting trademarks is not the matter of only firms and companies, and population of China makes a significant contribution thereto.

These figures justify the fact that consequently the firms and companies of the countries which pay a particular attention to the $R \& D$, allocate huge volumes of investments on the $R \& D$ and thus obtain a good reputation and can get huge profits which are constantly increasing. Hence the expenses made on the $R \& D$ will definitely be beneficial. Such countries will raise their welfare not due to material assets, but due to intangible assets based on innovative ideas. And this is true. The urgency and significance of this issue has been emphasized by Sh. Mirziyoyev, the President of the Republic of Uzbekistan: "Currently we are shifting to the innovation development path aimed at the fundamental renewal of the state and society. This fact is definitely not without a reason. Because who will win in the current times of the rapid development? The state which owns a new idea, new thought, which relies on the innovations, will benefit".

Despite the impact of the pandemic, as it has been mentioned above, Uzbekistan is trying to do it best to take its own place in the creation and development of the World Intellectual Property ecosystem. The intellectual property ecosystem in Uzbekistan is under development, and services are provided remotely. The Intellectual Property Agency of Uzbekistan is a permanent and reliable partner of the World Intellectual Property Organization. The agency carries out its activities in the form of online. That is, intellectual property services have not stopped. Today, all events and meetings at the Intellectual Property Agency are held in the format of video conferences and webinars.

Table 8: Intellectual property objects included in the register by the Intellectual Property Agency in the pandemic

\begin{tabular}{|c|c|c|c|c|c|c|c|c|c|}
\hline \multirow[t]{2}{*}{ Indicators } & \multicolumn{8}{|c|}{ January-August 2020} & \multirow{2}{*}{$\begin{array}{c}\text { Compared } \\
\text { to } \\
\text { January, \% }\end{array}$} \\
\hline & 01.01 & 01.02. & 01.03 & 01.04 & 01.05 & 01.06 & 01.07 & 01.08 & \\
\hline Total: & 322 & 405 & 387 & 402 & 363 & 120 & 340 & 382 & $+18,6$ \\
\hline Invented & 33 & 33 & 25 & 38 & 17 & 22 & 21 & 10 & $-69,7$ \\
\hline
\end{tabular}




\begin{tabular}{|l|c|c|c|c|c|c|c|c|c|}
\hline Useful model & 13 & 17 & 9 & 8 & 10 & 4 & 10 & 11 & $\mathbf{- 1 5 , 4}$ \\
\hline $\begin{array}{l}\text { Industrial } \\
\text { design }\end{array}$ & 12 & 8 & 13 & 9 & 14 & 5 & 6 & 5 & $\mathbf{- 5 8 , 4}$ \\
\hline Trademark & 125 & 113 & 117 & 151 & 120 & 51 & 77 & 205 & $\mathbf{+ 6 4 , 0}$ \\
\hline Software & 128 & 230 & 199 & 181 & 200 & 31 & 222 & 148 & $\mathbf{+ 1 5 , 6}$ \\
\hline Database & 2 & 4 & 3 & 3 & 2 & 3 & 1 & 2 & - \\
\hline $\begin{array}{l}\text { Selection } \\
\text { achievements }\end{array}$ & 19 & 5 & 16 & 5 & - & 4 & 1 & 1 & $\mathbf{- 9 9 , 5}$ \\
\hline
\end{tabular}

The table shows that in January-August 2020, there was almost no change in the order of registration of intellectual property by Uzbekistan IMA (excluding June, it decreased by 3 times on average). Even this figure increased in August compared to January 2020 (+60 units or $118.6 \%$ ). That is, the level of services provided by the Agency has improved despite the pandemic. For example, the number of trademark registrations in the intellectual property sector was 125 in January, an increase of 205 (+80 or $164 \%$ ) by August. The total number of IP registered by the agency in August 2019 was also prevented from falling sharply under the influence of the pandemic (from 450 in August 2019 to 84.8\% compared to August 2020). Of course, this is due to the rapid economic reforms in the country in the context of the pandemic. As a result, Uzbekistan was recognized in the Innovation Index of the World Intellectual Property Organization on the indicator: "Human Capital \& Research".

One of the important issues on the development of the intellectual property ecosystem in the Republic of Uzbekistan is to strengthen the legal basis of the technologies of the nearet future. Currently economists, scientists, accountants and specialists are concerned with the question whether 3D model (CAD file) will be recognized as a separate object of the intellectual property or it will remain as a structural element of the software for computing devices. From the point of view of other group of researchers, the problem is that by the legal protection of the intellectual property both 3D-printers and software programs have the same essence and should be protected as the work of authorship. At first sight it seems that there is no difference between the software for computing devices and 3D model (CAD file).

In our opinion, with the aim of further development of the legal bases for intellectual property ecosystem it is recommended to introduce the following articles of the Civil Code of the Republic of Uzbekistan:

To article 1041: By "Copyright object": "Three dimension object (e-model)";

To article 1042: By the types of the copyright objects: "Special software, its electronic model (CAD file), printing device (3D printer) and three dimension form (3D object)";

To article 1050: By the protection signs of the copyright: "letter " $D$ " in Latin alphabet inside a circle".

Thus, 3D model (CAD file) proposed as an advanced technology for future is not considered to be a structural element of the software for computing devices, but as a new type of the object of the intellectual property ecosystem. This, in turn, enables to enhance the volume of innovation products.

\section{Conclusion and proposals.}

The following measures should be undertaken for developing the intellectual property ecosystem and innovation activity in the republic:

development of drafts of new statutory acts aimed at improving the competitiveness of the national innovation system;

bringing copyright protection legislation in compliance with the international standards; 
creation of the national innovation system which absorbs the world scientific research innovations and possibilities for their implementation;

when financing research field, allocating funds to fundamental research areas and practical activities of the private sector;

improvement of mechanisms for commercialization of research results, providing appropriate incentives for the creation of innovative technoparks in the regions;

proceeding from the peculiarities of the national economy establishment of the innovation centres at the local level;

development of innovation determining standards with the account of the world standards;

encouraging establishment of research and project institutes at the branch enterprises and gradual application of international standards into the patenting system of the republic;

it is necessary to create a special "customerresearcher-investor" chain for commercialization of scientific research and to implement the mechanism encouraging introduction of scientific achievements in the economy.

Efficient criteria of the intellectual property ecosystem will be demonstrated in the following aspects:

first, it will be designed for commercialization of innovation products of the successful intellectual property ecosystem;

second, efficient intellectual property ecosystem will ensure constant change of existing and generating new ideas;

third, efficient intellectual property ecosystem represents a collaborative network of professionals who provide continuity in the creation of innovative products.

In conclusion it should be noted that by 2021-2030 Uzbekistan has been assigned the task to reach and be included in the list of international ratings and indices, such as Global Competitiveness Index, World Economic Forum, Global Innovation Index, INSEAD International Business School, Cornell University, World Intellectual Property
Organization (WIPO), Global Green Economy Index - Dual Citizen LLC, as well as Competitive Industrial Performance Index by the United Nations Industrial Development Organization, UNIDO.

This means that global economic growth will not return to pre-pandemic levels. We have to get used to it, intellectual property has been badly damaged by the pandemic, but the pandemic has taught us to work together more than ever. We will definitely overcome this pandemic disaster and endure its hardships. Human capital and intellectual property will continue to grow and develop. The creation of new intellectual property in the world will never stop.

\section{I can say with confidence that intellectual property can overcome any coronavirus pandemic!}

\section{REFERENCES}

[1] Brooking A., Motta E.A (1996) Taxonomy of Intellectual Capital and Methodology for Auditing It/17th Annual National Business Conference, McMaster University, Hamilton, Ontario, Canada. January 24-26.

[2] Frost \& Sullivan http://www.tadviser.ru/

[3] Forecast: 3D-Printers, Worldwide, 2018, Gartner, 17 September 2018, G00277739. https://www.gartner.com/doc/3132417/for ecast-d-printers

[4] Tadviser http://www.tadviser.ru/index.php.

[5] Worldwide-research https://www.statista.com/statistics/732247

[6] Worldbank https://data.worldbank.org/indicator/gb.xp d.rsdv.gd.zs

[7] Stewart T.A. Intellectual Capital. The New Wealth of Organizations. N.Y.-L., Doubleday / Currency, 1997. Copyright T.A.Stewart 1997.

[8] Sveiby K.E. Intellectual Capital and Knowledge Management.1998.-213 p. 
[9] Thomas P. Carlin. Albert R. Makmin, III. Analysis of financial statements (on the GAAP basis). Textbook. Translation of the IV-th English edition. M.: INFRAM.1998.-448p.

[10] Leontyev B.B. (2002). Price for intellect Intellectual capital in Russian business. M.: «Aktsioner».

[11] Dontsova L. Analysis of Financial Statements: Textbook, $6^{\text {th }}$ edition. Edited. "Delo i Service" publishing house, 2008. $368 \mathrm{p}$.

[12] Ivanov I.V et al (2008). Financial Management: Cost approach: educational aid. -M.: Alpina Business Books.

[13] Lytneva L. (2006). Accounting. Textbook: M-Forum: INFRA-M, -496 p.

[14] Pokrovskiy И.А (1894). The role of Roman law in the legal history of mankind and in modern jurisprudence // Scientific notes of Yuriev University.

[15] Mirziyoyev Sh. M. (2017). Message of Shavkat Mirziyoyev, the President of the Republic of Uzbekistan to the Oliy Majlis. December 22, 2017.

[16] Decree (2018). Decree of the President of the Republic of Uzbekistan №5544 “On approving the strategy for innovative development of the Republic of Uzbekistan for 2019 - 2021" as of September 21, 2018.

[17] Decree (2019). Decree of the President of the Republic of Uzbekistan №5544 “On approving the strategy for innovative development of the Republic of Uzbekistan for 2019 - 2021" as of September 21, 2018.

[18] UNESCO

(2019).http://uis.unesco.org/sites/

[19] https://rg.ru/2018/10/21/kak-upravliatintellektualnoj-sobstvennostiu.

[20] Brand Finance NB. 2018. http://brandfinance.com/who-we-are/ourstory/.
[21] Brand Finance GIFT 2016 with CIMA and IPA $\quad 2016 \quad 10 \quad$ P. enquiries@brandfinance.com

[22] http://brandfinance.com/images/upload/glo bal_500_2019_locked.pdf

[23] http://www.wipo.int/ipstats/en/index.html Source: WIPO Statistics Database, March, 2018.

[24] https://www.wipo.int/edocs/infogdocs/en/i pfactsandfigures 2018/

[25] https://www.wipo.int/edocs/infogdocs/en/2 018/ (Facts and Figures-2018).

[26] http://www.wipo.int/edocs/infogdocs/en/ 2018/ (PCT top tech fields).

[27] https://www.wipo.int/ipstats/ru/

[28] http://www.wipo.int/edocs/infogdocs/2018 . (Madrid top 10 countries)

[29] https://www.wipo.int/portal/en/index.html

[30] https://ru.wikipedia.org/wiki/.

[31] https://medlife.uz/ (Ekotizim (2019).

[32] https://mininnovation.uz/

[33] https://president.uz/uz/3158

[34] http://financials.morningstar.com/balancesheet/bs.html? $\mathrm{t}=\mathrm{GM}$.

[35] https://www.columbia.edu/ (Columbia University).

[36] https://innovation.ox.ac.uk/universit (University of Oxford).

[37] https://www.wipo.int/edocs/pubdocs/en/wi po_pub_gii_2020/uz.pdf

[38] Temirkhanova M.Zh. Issues of improving financial reporting in travel companies based on the requirements of international standards (IAS IFRS). Bulletin of Science and Practice. 2018.Vol. 4.No. 3.P. 217223.

[39] Temirkhanova M.Zh. Improving the methodology of organizing financial accounting in travel companies. Bulletin of Science and Practice. 2018.Vol. 4.No. 3.P. 267-273.

[40] Temirkhanova M.Zh. Problems in improving the approximation to international standards for reporting financial results in travel companies. 
Kaluga Economic Bulletin. 2018.No. 4.P. 59-61.

[41] Temirkhanova M.Zh. Organization of accounting of liabilities in a travel company. Economy and entrepreneurship. 2016. No. 11-2 (76). S. 879-882.

[42] Temirkhanova M.Zh. Improving information technology planning when introducing cost accounting in travel companies and organizing the rules for accounting when calculating financial results. In the collection: Scientific research in the socio-economic development of society. International scientific and practical conference of scientific and pedagogical workers. 2019.S. 438-442.

[43] Temirkhanova M.Zh. Estimation of the value of objects of intellectual property in accounting in the Republic of Uzbekistan. In the collection: Engineering economics and management in modern conditions. Materials of the scientific-practical conference dedicated to the 50th anniversary of the Faculty of Engineering and Economics. Executive editor V.V. Zhilchenkova. 2019.S. 684-691.

[44] Temirkhanova M.Zh., Bakirova M.Sh.K. Improving accounting and auditing of intellectual property objects. In the collection: Scientific research in the socioeconomic development of society. International scientific and practical conference of scientific and pedagogical workers. 2019.S. 443-447. 